\title{
CLINICAL AND DIAGNOSTIC ASPECTS OF ABNORMAL UTERINE BLEEDING IN REPRODUCTIVE AGED WOMEN WITH EXTRAGENITAL PATHOLOGY
}

\section{INTRODUCTION}

Abnormal uterine bleeding (AUB) occupies one of the central places among gynecological problems [1]. AUB frequency depends to a large extent on age: it is much more common in adolescence and in patients over 50 and in $30 \%$ of reproductive age women [2]. World prevalence of AUB is not the same, which is probably due to the standard of patients' living, material and technical base of medical institutions for modern differential diagnosis, as well as the specialists' qualifications [3]. Statistics show that a significant number of women with AUB do not seek medical care even if it is available. AUB, developing in the reproductive period and not associated with pregnancy, is characterized by an increase in the menstruation duration, significant blood loss, or an increase in bleeding episodes [4,5]. Long-term AUB associated with asthenic syndrome, anemia, fatigue, depression development, a significant decrease in labor productivity, disrupt normal daily life, resulting in a significant deterioration in the life quality of women with a simultaneous increase in the burden on the health care system $[6,7]$.

Both gynecological and extragenital pathology are of great importance in the etiopathogenesis of AUB. The reason for this lies in the endometrium ability as a hormone-dependent target organ to respond to any changes in the hormonal body status as a whole, and is also associated with the participation of various organs and systems in the metabolism of sex hormones [8,9]. There is also an interdependence of other organs and systems in the reproductive system functioning: cardiovascular system, endocrine function and metabolism. Thus, in hypertension, there is a tendency to hypercoagulability, which contributes to the rapid depletion of coagulation factors and disseminated intravascular coagulation; vasospasm disrupts the blood supply to the vascular wall; increased pressure directly has an adverse effect on the vascular wall, which aggravates bleeding. Secondary to metabolic endocrine disorders, in particular obesity, dyslipidemia causes atherosclerotic damage of the vascular wall; an increase in leptin leads to hyperinsulinemia and insulin resistance, hyperglycemia as a result of various hormonal and metabolic disorders has a vasospastic, damaging effect on the vascular wall and an increase in the thrombogenic potential of the endothelium, aggravating bleeding [10-15].
Approximately $20 \%$ of patients with AUB suffer from bleeding disorders [16]. Von Willebrand disease and platelet dysfunction are the most common coagulopathies associated with AUB [17].

AUB can be triggered by a variety of medical procedures and/or prescriptions. Hormonal contraceptives are a common cause of iatrogenic uterine bleeding [18]. Other causes include non-contraceptive hormone therapy, the use of drugs that interfere with the function or synthesis of sex steroid hormones (e.g. tamoxifen), anticoagulants and dopamine antagonists (e.g. tricyclic antidepressants) [19].

Factors influencing the development of AUB can include infectious diseases, climate change, intoxication, harmful working conditions, acute/chronic stress, changes in the nature of nutrition, loss or increase in body weight [20].

Thus, in order to achieve the menstrual cycle normalization and prevention of AUB, it is necessary to impact all links of AUB pathogenesis, in particular, the hormonal background, factors of hemostasis and local factors that regulate the endometrium functioning.

Study objective: to determine the clinical and diagnostic features of AUB in women of reproductive age with extragenital pathology.

\section{MATERIALS AND METHODS}

The study involved a retrospective assessment of 400 case histories of reproductive aged women with AUB who underwent inpatient treatment at the communal non-profit enterprise "City Maternity Hospital No. 1" of Kharkiv City Council (clinical base of the Department of Obstetrics, Gynecology and Pediatric Gynecology, Kharkiv National Medical University, Kharkiv, Ukraine) for the period 2015-2019.

The main clinical group (I) consisted of 300 case histories of women with AUB and concomitant extragenital disorders, control group (II) comprised 100 case histories of somatically healthy women with AUB.

Selection of case histories was carried out according to the following inclusion criteria: age 18-45 years, presence or absence of extragenital diseases, complaints of menstrual disorders, such as uterine bleeding for more than 8 days, and/or with a volume of more than $80 \mathrm{ml}$, and/or with an interval of less than 24 days, or more than 4 episodes in 90 days $[18,21]$, body mass index $18-40 \mathrm{~kg} / \mathrm{m}^{2}$.

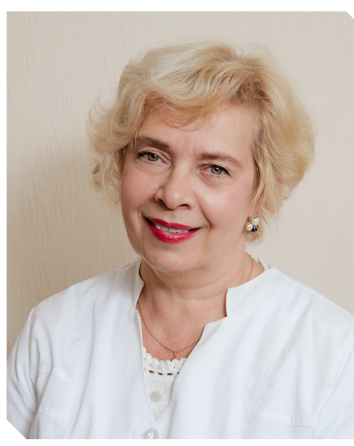

I.A. TUCHKINA

$M D$, professor, head of the Department of Obstetrics, Gynecology and Pediatric Gynecology, Kharkiv National Medical University, Kharkiv ORCID: 0000-0003-4280-1474

L.A. VYGIVSKA

MD, associate professor, Department of Obstetrics, Gynecology and Pediatric Gynecology, Kharkiv National Medical University, Kharkiv

ORCID: 0000-0002-9389-4845

E.V. BLAGOVESHCHENSKY

PhD, associate professor, Department

of Obstetrics, Gynecology and

Pediatric Gynecology, Kharkiv

National Medical University

ORCID: 0000-0002-0735-6515

R.E. BLAGOVESHCHENSKY

graduate student, Department of Obstetrics, Gynecology and Pediatric Gynecology, Kharkiv National Medical University, Kharkiv

ORCID: 0000-0003-3022-8180

Contacts:

Liudmyla A. Vygivska

Kharkiv National Medical University, Department of Obstetrics, Gynecology and Pediatric Gynecology Nauky avenue 4

61022, Kharkiv, Ukraine

Tel.: +38 (050) 9675487 email: liudmilavygovskaya@gmail.com 
The exclusion criteria were: no menarche or menopausal status, hysterectomy, oophorectomy, pregnant and lactating women.

All women underwent ultrasound examination with Doppler mapping to assess the condition of the pelvic organs according to the standard technique with a MINDRAY M8 ultrasound scanner using abdominal and vaginal convex transducers with a frequency of 3.5-7.5 MHz [22, 23].

All women underwent hysteroscopy and/or separate diagnostic curettage with further morphological assessment of the endometrium state [24, 25]. The diagnosis of atypical endometrial hyperplasia and/or endometrial polyps was histologically confirmed.

All examined women were consulted by related specialists for the diagnosis of extragenital disorders.

In terms of evidence-based medicine the study is categorized as "case series". Statistical data analyzed with general-purpose data processing software package "Statistic for Windows" version 6.1. Interval scale data are presented as $M \pm m$, where $M$ is the sample mean; $m$ is the error of mean. Frequency analysis was used to represent the data on the nominal scale.

\section{STUDY RESULTS AND DISCUSSION}

The average age of patients in both groups was $32 \pm 14$ years. The most common extragenital pathology was diseases of the circulatory, endocrine and digestive systems (Table 1).

\begin{tabular}{|c|c|}
\hline Extragenital pathology & Incidence \\
\hline $\begin{array}{l}\text { Circulatory diseases } \\
\text { - hypertonic disease } \\
\text { - varicose veins of the lower extremities }\end{array}$ & $\begin{array}{c}80(26 \%) \\
97(32.3 \%)\end{array}$ \\
\hline $\begin{array}{l}\text { Digestive diseases } \\
\text { - chronic cholecystitis } \\
\text { - chronic gastritis } \\
\text { - cholecystectomy } \\
\text { - chronic colitis } \\
\text { - chronic pancreatitis }\end{array}$ & $\begin{array}{c}15(5 \%) \\
87(29 \%) \\
8(2.6 \%) \\
11(3.6 \%) \\
9(3 \%)\end{array}$ \\
\hline $\begin{aligned} & \text { Genitourinary diseases } \\
& \text { - } \text { chronic pyelonephritis } \\
& \text { - chronic cystitis }\end{aligned}$ & $\begin{array}{c}23(7.6 \%) \\
18(6 \%)\end{array}$ \\
\hline $\begin{aligned} & \text { Endocrine diseases } \\
& \text { - } \text { obesity } \\
& \text { - nodular goiter } \\
& \text { - diabetes }\end{aligned}$ & $\begin{array}{c}143(47.6 \%) \\
12(4 \%) \\
27(9 \%)\end{array}$ \\
\hline $\begin{array}{l}\text { Respiratory diseases } \\
\text { - chronic tonsillitis } \\
\text { - chronic bronchitis }\end{array}$ & $\begin{array}{c}31(10.3 \%) \\
15(5 \%)\end{array}$ \\
\hline $\begin{array}{l}\text { Nervous diseases } \\
\text { - multiple sclerosis }\end{array}$ & $1(0.3 \%)$ \\
\hline $\begin{array}{l}\text { Diseases with impaired nervous regulation } \\
\text { of the circulatory system } \\
\text { - somatoform autonomic dysfunction }\end{array}$ & $46(15 \%)$ \\
\hline
\end{tabular}

Moreover, 123 patients (41\%) had concomitant hypertension and obesity, 76 (25.3\%) had obesity and varicose veins, 53 (17.6\%) had somatoform autonomic dysfunction and chronic gastritis, 39 (13\%) had obesity and diabetes mellitus, 24 (8\%) had chronic gastritis and obesity.

Assessment of past histories showed that most frequently the patients had chickenpox, measles, rubella, mumps, hepatitis $A$, SARS. There was no statistically significant difference in the in- cidence of these diseases in the histories between the clinical groups ( $p$ <.05). Attention was drawn to the high incidence of gynecological diseases in all examined patients. Evaluation of the gynecological history and comprehensive physical examination established a significant excess of the incidence of gynecological disorders, against the background of which AUB developed in patients with extragenital diseases $(p<0.05)$ (Table 2).

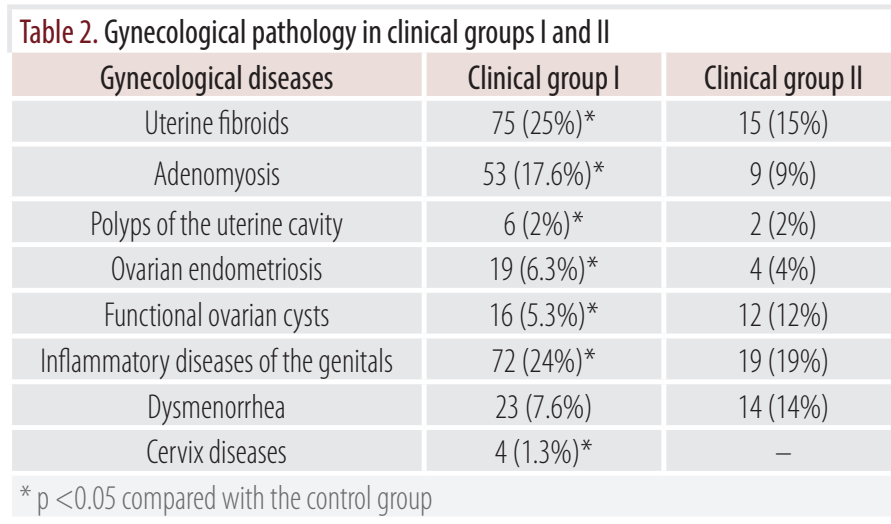

Most often, gynecological disorders in clinical groups included uterine fibroids, inflammatory diseases of the pelvic organs, adenomyosis and dysmenorrhea syndrome.

To establish the cause of AUB and select the most rational treatment tactics, all patients underwent a clinical blood test, coagulogram, hormonal profile (Table 3), ultrasound of the pelvic organs (transvaginal and/or abdominal) to assess the endo- and myometrium. Doppler study was used to obtain additional information on the nature of the endometrium and myometrium disorders.

Hysterography was performed with a therapeutic and diagnostic purpose, especially in cases where the information content of transvaginal ultrasound was insufficient, as well as, if necessary, to clarify the state of the uterine cavity and focal intrauterine disorder.

\begin{tabular}{|c|c|c|}
\hline \multicolumn{2}{|c|}{ Table 3. Laboratory indices in clinical groups I and II } \\
\hline Laboratory indices & Clinical group I & Clinical group II \\
\hline Hemoglobin, $10 \mathrm{~g} / \mathrm{l}$ & $91 \pm 20$ & $117 \pm 9$ \\
\hline Platelets, $10^{19} / /$ & $180 \pm 30$ & $210 \pm 30$ \\
\hline Prothrombin index, $\%$ & $80 \pm 20$ & $85 \pm 15$ \\
\hline Fibrinogen, $\mathrm{g} / \mathrm{C}$ & $2.4 \pm 0.4$ & $2.9 \pm 0.9$ \\
\hline
\end{tabular}

AUB was complicated by anemia of varying severity in 176 (58.6\%) women.

Coagulogram indices remained within the normal range in group II, while in group I there was a slight decrease in these indicators.

Ultrasound examination showed an endometrial hyperplasia in all examined women. The endometrial thickness was $26 \pm 8$ $\mathrm{mm}$. Endometrium structure did not correspond to the middle stage of the secretion phase in 123 (41\%) patients in group I and 47 (47\%) women in group II. There was a pronounced three-layer structure of the endometrium with a diffuse increase in the density of the functional layer on the border with the basal one. This picture corresponded to the periovulatory state of the mucous membrane of the uterine cavity, which is characteristic of acute active glandular hyperplasia of the endometrium. 
Endometrium structure corresponded to chronic active glandular hyperplasia in 107 (35.6\%) women in group l and 22 (22\%) women in group II. Mucous membrane was characterized by a uniform increase in density and a homogeneous structure, a high-density dividing strip was observed in the center, and an echo-negative rim along the periphery. This condition of the mucous membrane indicated the predominance of proliferative processes.

In 41 (13.6\%) women in clinical group I and 17 (17\%) women in clinical group II, against the background of increased thickness and increased echogenicity of the endometrium, zones of decreased echo density of a heterogeneous shape were observed, which made the structure of the endometrium seemed heterogeneous. This ultrasound picture was typical for glandular cystic hyperplasia of the endometrium.

Single point color vascular signals were determined when performing Doppler mapping in the basal layers of the endometrium. The vascular resistance index was $0.43 \pm 0.04$.

In 22 (7.3\%) women in group I and $8(8 \%)$ women in group II there were a single and multi-natural echo-negative inclusions in the endometrial structure against the background of a regular shaped hyperechoic structure of the endometrium with clear even contours of various diameters from 2 to $8 \mathrm{~mm}$, which corresponded to the structure of the glandular polyp.
Irregular rounded shape formations with clear contours from 3 to $10 \mathrm{~mm}$ were visualized in 7 (2.3\%) women in group I and $6(6 \%)$ women in group II with small areas of low density surrounded by hyperechoic rims, which was regarded as a glandular fibrous polyp.

Color Doppler mapping detected a vascular signal in the area of the polyp pedicle, and the resistance index was $0.45 \pm 0.02$.

Thus, according to ultrasound data the most common endometrial disorder in women of clinical group I was glandular hyperplasia of the endometrium.

\section{CONCLUSION}

A retrospective assessment of case histories showed a high AUB prevalence among women with extragenital pathology, which is a clinical indicator of major menstrual disorders in this category of patients and can be a serious problem for women's health in general. The need to study the prevalence and identify the main risk factors for AUB development will make it possible to provide a general strategy for it prevention, improve the reproductive potential of women and avoid serious abnormal changes in the process of fulfilment of the reproductive function in young women.

\section{REFERENCES/ЛІTЕPATУPA}

\section{Oberman, E., Rodriguez-Triana, V.}

"Abnormal Uterine Bleeding: Treatment Options." Clin Obstet Gynecol 61.1 (2018): 72-5.

2. Tuchkina, I.0., Vygivska, L.A., Novikova, A.A.

"Abnormal uterine bleeding in adolescents: current state of the problem."Wiad Lek LXXIII.8 (2020): 1752-5. D0I: 10.36740/

WLek202008130

3. Munro, M.G., et al.

"The two FIGO systems for normal and abnormal uterine bleeding symptoms and classification of causes of abnormal uterine bleeding in the reproductive years: 2018 revisions."Int I Gynaecol Obstet 143.3 (2018): 393-408.

4. Bofill, R.M., Lethaby, A., Farquhar, C.

"Non-steroidal anti-inflammatory drugs for heavy menstrual

bleeding." Cochrane Database Syst Rev 9.9 (2019): CD000400.

5. Kotagasti, T.

"Prevalence of different menstrual irregularities in women with abnormal uterine bleeding (AUB) - an observational study."Int J Cur Res Rev 7.10 (2015): 66-70.

6. Karlsson, T.S., Marions, L.B., Edlund, M.G.

"Heavy menstrual bleeding significantly affects quality of life."

Acta Obstet Gynecol Scand 93.1 (2014): 52-7.

7. Hapangama, D.K., Bulmer, J.N.

"Pathophysiology of heavy menstrual bleeding."Womens

Health (Lond) 12.1 (2016): 3-13.

8. Никитина, Т.И.

Структура аномальных маточных кровотечений у женщин репродуктивного возраста. Применение современной

классификации PALM-COEIN / Т.И. Никитина, В.Б. Осадчев,

К.В. Бабков // Фарматека. - 2016. - №3. - C. 47-50.

Nikitina, T.I., Osadchev, V.B., Babkov, K.V.

"The structure of abnormal uterine bleeding in women of reproductive age. Application of the modern PALM-COEIN

classification." Pharmacy 3 (2016): 47-50.

9. Hale, K.

"Abnormal Uterine Bleeding: A Review." US Pharm 43.9 (2018): HS2-HS9.

10. Тананакина, Е.H.

Эффективность препарата мелатонина у женщин репродуктивного возраста с аномальным маточным кровотечением и комбинированной экстрагенитальной патологией / Е.Н. Тананакина // Акушерство, гинекология и репродукция. - 2014. - №8 (3). - С. 31-38.

Tananakina, E.N.

"Efficacy of melatonin in women of reproductive age with abnormal uterine bleeding and combined extragenital disorders." Obstetrics, Gynecology and Reproduction 8.3 (2014): 31-8. 11. Тучкина. И.А.

Диагностика и лечение подростков и молодых женщин с аномальными маточными кровотечениями и ретенционными кистами яичников на фоне экстрагенитальной патологии / И.А. Тучкина, О.В. Гнатенко, М.Ю. Тучкина // Збірник наукових праць Асоціації акушерівгінекологів України. - 2018. - Вип. 2 (42). - С. 191-197.

Tuchkina, I.A., Gnatenko, O.V., Tuchkina, M.Y.

"Diagnosis and treatment of adolescents and young women with abnormal uterine bleeding and retention ovarian cysts secondary to extragenital disorders." Collection of scientific

works of the Association of Obstetricians and Gynecologists of Ukraine 2.42 (2018): 191-7.

12. Tuchkina, I.A., Tuchkina, M.Y., Novikova, A.A.

"Treatment of adolescent girls with abnormal uterine bleeding taking into account psychoemotional and: vegetative status." Journal of Education, Health and Sport 9.5 (2019): 575-82.

13. Патент № 132207 Україна, MПK G01N 33/48 (2006.01). Спосіб оцінки ефективності профілактичного лікування атипової гіперплазії ендометрія в перименопаузі у жінок з абдомінальним ожирінням // І.0. Тучкіна, І.А. Гузь,

Є.В. Благовещенський та ін. - №201810104; заява

10.10.2018; друк. 11.02.2019.

Patent No. 132207 Ukraine, MPK G01N 33/48 (2006.01).

Method for evaluating the effectiveness of preventive treatment of atypical endometrial hyperplasia in perimenopause in women with abdominal obesity / Tuchkina, I.O., et al.; No. 201810104; appl. 10.10.2018; publ. 11.02.2019.

14. Töz, E, Sanc, M., Özcan, A., et al.

"Comparison of classic terminology with the FIGO PALM-COEIN system for classification of the underlying causes of abnormal uterine bleeding." Int J Gynaecol Obstet 133.3 (2016): 325-8. 15. Fraser, I.S., Munro, M.G., Critchley, H.O.

"Best Practice Issue on «Abnormal Uterine Bleeding." Best Pract Res Clin Obstet Gynaecol 40 (2017): 1-2.
16. Knol, H.M., et al.

"The prevalence of underlying bleeding disorders in patients with heavy menstrual bleeding with and without gynecologic abnormalities." Am J Obstet Gynecol 209.3 (2013):

202.e1-202.e7.

17. Dickerson, K.E., Menon, N.M., Zia, A.

"Abnormal Uterine Bleeding in Young Women with Blood Disorders." Pediatr Clin North Am 65.3 (2018): 543-60.

18. Munro, M.G., et al.

"FIGO classification system (PALM-COEIN) for causes of abnormal uterine bleeding in nongravid women of reproductive age."Int J Gynaecol Obstet 113.1 (2011): 3-13.

19. Wouk, N., Helton, M.

"Abnormal Uterine Bleeding in Premenopausal Women." Am Fam Physician 99.7 (2019): 435-43.

20. Davis, E., Sparzak, P.B.

Abnormal uterine bleeding (dysfunctional uterine bleeding). StatPearls Publishing (2018). Available from: [https://www.

ncbi.nlm.nih.gov/books/NBK532913].

21. Чернуха, Г.Е.

Диагностика и медикаментозная терапия маточных кровотечений с позиций международных рекомендаций / Г.Е. Чернуха, Ю.И. Немова // Акушерство и гинекология. 2013. - № 2. - C. 2-7.

Chernukha, G.E., Nemova, Y.I.

"Diagnosis and drug therapy of uterine bleeding according to international recommendations." Obstetrics and Gynecology 2 (2013): 2-7.

22. Wheeler, K.C., Goldstein, S.R.

"Transvaginal Ultrasound for the Diagnosis of Abnormal Uterine

Bleeding." Clin Obstet Gynecol 60.1 (2017): 11-17.

23. Pecchioli, Y., Oyewumi, L., Allen, L.M., Kives, S.

"The Utility of Routine Ultrasound in the Diagnosis and

Management of Adolescents with Abnormal Uterine Bleeding."

J Pediatr Adolesc Gynecol 30.2 (2017): 239-42.

24. Davies, J., Kadir, R.A.

"Heavy menstrual bleeding: An update on management." Thromb Res 151.1 (2017): S70-S77.

25. Kolhe, $S$.

"Management of abnormal uterine bleeding - focus on

ambulatory hysteroscopy." Int J Womens Health 10 (2018): $127-36$. 


\section{CLINICAL AND DIAGNOSTIC ASPECTS OF ABNORMAL UTERINE BLEEDING IN REPRODUCTIVE AGED WOMEN WITH EXTRAGENITAL PATHOLOGY}

I.A. Tuchkina, MD, professor, head of the Department of Obstetrics, Gynecology and Pediatric Gynecology, Kharkiv National Medical University, Kharkiv L.A. Vygivska, MD, associate professor, Department of Obstetrics, Gynecology and Pediatric Gynecology, Kharkiv National Medical University, Kharkiv E.V. Blagoveshchensky, PhD, associate professor, Department of Obstetrics, Gynecology and Pediatric Gynecology, Kharkiv National Medical University, Kharkiv R.E. Blagoveshchensky, graduate student, Department of Obstetrics, Gynecology and Pediatric Gynecology, Kharkiv National Medical University, Kharkiv Study objective: to determine the clinical and diagnostic features of the abnormal uterine bleeding (AUB) in women of reproductive age with extragenital pathology.

Materials and methods. The study involved a retrospective assessment of 400 case histories of reproductive aged women with AUB who underwent inpatient treatment.

The main clinical group (I) consisted of 300 case histories of women with AUB and concomitant extragenital disorders, control group (II) consisted of 100 case histories of somatically healthy women with AUB. An ultrasound scan with Doppler mapping was performed to assess the pelvic organs. All women underwent hysteroscopy and/or separate diagnostic curettage with further morphological assessment of the endometrium.

Results. The most common extragenital disorder was diseases of the circulatory system and endocrine system, diseases of the digestive system. 123 patients (41\%) had concomitant hypertension and obesity, 76 (25.3\%) - obesity and varicose veins, 53 (17.6\%) - somatoform autonomic dysfunction and chronic gastritis, 39 (13\%) - obesity and diabetes mellitus, 24 (8\%) - chronic gastritis and obesity. AUB was complicated by anemia of varying severity in 176 (58.6\%) women. According to ultrasound data the most common endometrial disorder in women of group I was glandular hyperplasia of the endometrium.

Conclusion. A retrospective analysis of case histories showed a high prevalence of AUB among women with extragenital pathology, which is a clinical indicator of major menstrual disorders in this category of patients and can be a serious problem for women's health in general. The need to study the prevalence and identify the main risk factors for the AUB development will make it possible to provide a general strategy for its prevention, improve the reproductive potential of women and avoid serious abnormal changes in the process of fulfilment of the reproductive function in young women.

Keywords: abnormal uterine bleeding, extragenital pathology, reproductive age, ultrasound examination, Doppler imaging, hysteroscopy, diagnostic curettage.

\section{КЛІНІКО-ДІАГНОСТИЧНН АСПЕКТИ АНОМАЛЬНИХ МАТКОВИХ КРОВОТЕЧ У ЖІНОК РЕПРОДУКТИВНОГО ВІКУ З ЕКСТРАГЕНІТАЛЬНОЮ ПАТОЛОГІЕЮО}

І.О. Тучкіна, д. мед. н., професор, зав. кафедри акушерства, гінекології та дитячої гінекології Харківського НмУ, м. Харків

Л.А. Вигівська, д. мед. н., доцент кафедри акушерства, гінекології та дитячої гінекології Харківського НМУ, м. Харків

Є.В. Благовещенський, к. мед. н., доцент кафедри акушерства, гінекології та дитячої гінекології Харківського НМУ, м. Харків

Р.Є. Благовещенський, аспірант кафедри акушерства, гінекології та дитячої гінекології Харківського НМУ, м. Харків

Мета: визначення клініко-діагностичних особливостей аномальних маткових кровотеч (АМК) у жінок репродуктивного віку з екстрагенітальною патологією.

Матеріали та методи. Проведено ретроспективний аналіз 400 історій хвороби жінок репродуктивного віку, які перебували на стаціонарному лікуванні 3 приводу АМК. Основну клінічну групу (I) склали 300 історій хвороби жінок із АМК та наявністю супутньої екстрагенітальної патології, групу контролю (II) - 100 історій хвороби соматично здорових жінок з АМК. Для оцінки стану органів малого таза було проведено УзД з доплерометричним картуванням. Всім жінкам була виконана гістероскопія та/або роздільне діагностичне вишкрібання з подальшою морфологічною оцінкою стану ендометрія.

Результати. Екстрагенітальною патологією, яка зустрічалася найчастіше, були захворювання системи кровообігу та ендокринної системи, хвороби органів травлення. У 123 пацієнток (41\%) одночасно зустрічалися артеріальна гіпертензія й ожиріння, у 76 (25,3\%) - ожиріння і варикозне розширення вен, у 53 (17,6\%) - соматоформна вегетативна дисфункція і хронічний гастрит, у 39 (13\%) - ожиріння і цукровий діабет, у 24 (8\%) - хронічний гастрит і ожиріння. У 176 (58,6\%) жінок АМК ускладнилися анемією різного ступеня тяжкості. За даними УзД, у жінок І групи найчастішою патологією була залозиста гіперплазія ендометрія.

Висновок. Проведений ретроспективний аналіз історій хвороби показав високу поширеність АМК серед жінок із екстрагенітальною патологією, що є клінічним індикатором основних розладів менструальної функції у даної категорії хворих і може бути серйозною проблемою для жіночого здоров'я в цілому. Необхідність вивчення поширеності та виявлення основних факторів ризику розвитку АМК дасть можливість передбачити загальну стратегію профілактики даної патології, поліпшити репродуктивний потенціал жінок і уникнути серйозних патологічних змін в процесі реалізації репродуктивної функції у молодих жінок.

Ключові слова: аномальна маткова кровотеча, екстрагенітальна патологія, репродуктивний вік, ультразвукове дослідження, доплерометричне картування, гістероскопія, діагностичне вишкрібання.

\section{КЛИНИКО-ДИАГНОСТИЧЕСКИЕ АСПЕКТЫ АНОМАЛЬНЫХ МАТОЧНЫХ КРОВОТЕЧЕНИЙ У ЖЕНЩИН РЕПРОДУКТИВНОГО ВОЗРАСТА С КСТРАГЕНИТАЛЬНОЙ ПАТОЛОГИЕЙ}

И.А. Тучкина, Д. мед. Н., профессор, зав. кафедрой акушерства, гинекологии и детской гинекологии Харьковского НМУ, г. Харьков

Л.А. Выговская, Д. мед. Н., доцент кафедры акушерства, гинекологии и детской гинекологии Харьковского НМУ, г. Харьков

Е.В. Благовещенский, к. мед. н., доцент кафедры акушерства, гинекологии и детской гинекологии Харьковского НМУ, г. Харьков

Р.Е. Благовещенский, аспирант кафедры акушерства, гинекологии и детской гинекологии Харьковского НМУ, г. Харьков

Цель: определение клинико-диагностических особенностей аномальных маточных кровотечений (АМК) у женщин репродуктивного возраста с экстрагенитальной патологией. Материалы и методы. Проведен ретроспективный анализ 400 историй болезни женщин репродуктивного возраста, находившихся на стационарном лечении по поводу АМК. Основную клиническую группу (I) составили 300 историй болезни женщин с АМК и наличием сопутствующей экстрагенитальной патологии, группу контроля (II) - 100 историй болезни соматически здоровыХ женщин с АМК. Для оценки состояния органов малого таза было проведено УзИ с допплерометрическим картированием. Всем женщинам была выполнена гистероскопия и/или раздельное диагностическое выскабливание с дальнейшей морфологической оценкой состояния эндометрия.

Результаты. Наиболее часто встречающейся экстрагенитальной патологией были заболевания системы кровообращения и эндокринной системы, болезни органов пищеварения. у 123 пациенток (41\%) одновременно встречались артериальная гипертензия и ожирение, у 76 (25,3\%) - ожирение и варикозное расширение вен, у 53 (17,6\%) - соматоформная вегетативная дисфункция и хронический гастрит, у 39 (13\%) - ожирение и сахарный диабет, у 24 (8\%) - хронический гастрит и ожирение. У 176 (58,6\%) женщин АМК осложнилось анемией различной степени тяжести. По данным УЗИ, у женщин І группы наиболее частой патологией была железистая гиперплазия эндометрия.

Вывод. Проведенный ретроспективный анализ историй болезни показал высокую распространенность АМК среди женщин с экстрагенитальной патологией, что является клиническим индикатором основных расстройств менструальной функции у данной категории больных и может быть серьезной проблемой для женского здоровья в целом. Необходимость изучения распространенности и выявления основных факторов риска развития АМК даст возможность предусмотреть общую стратегию профилактики данной патологии, улучшить репродуктивный потенциал женщин и избежать серьезных патологических изменений при реализации репродуктивной функции у молодых женщин.

Ключевые слова: аномальное маточное кровотечение, экстрагенитальная патология, репродуктивный возраст, ультразвуковое исследование, допплерометрическое картирование, гистероскопия, диагностическое выскабливание. 